Original Research Paper

\title{
Formulation and Evaluation of Antioxidant Peel-Off Face Mask Containing Red Dragon Fruit Rind Extract (Hylocereus polyrhizus Haw.)
}

\author{
Trasna Arman Jani ${ }^{1}$, Aliefman Hakim², Yohanes Juliantoni ${ }^{1 *}$ \\ ${ }^{1}$ Program Studi Farmasi, Fakultas Kedokteran, Universitas Mataram, Mataram, Indonesia; \\ ${ }^{2}$ Program Studi Pendidikan Kimia, Fakultas Keguruan dan Ilmu Pendidikan, Universitas Mataram, Mataram, Indonesia;
}

\author{
Article History \\ Received : November $02^{\text {th }}, 2020$ \\ Revised : November $13^{\text {th }}, 2020$ \\ Accepted : November $18^{\text {th }}, 2020$ \\ Published : November $24^{\text {th }}, 2020$ \\ *Corresponding Author: \\ Yohanes Juliantoni, \\ Universitas Mataram, Mataram, \\ Indonesia; \\ Email: \\ juliantoni7753@gmail.com
}

\begin{abstract}
Peel-Off face mask is one of the cosmetics that is used to treat skin from free radicals. Peel-off face mask can minimize the effects of free radicals because it contains antioxidant. One of the antioxidant sources is red dragon fruit's rind (Hylocereuspolyrhizus Haw.). The aim of this study is to obtain Peel-Off face mask of red dragon fruit's rind extract that contains anthocyanin. Red dragon fruit's rind was macerated by ethanol $96 \%$, ethyl acetate and n-hexane added citric acid (4:1) solvents. TLC test used Chloroform: ethyl acetate: n-butanol (5:4:1) eluent and sprayed by $\mathrm{AlCl}_{3}$. Antioxidant activity of extract was tested using DPPH (1,1-Diphenyl-2Picryhidrazyl) method. Peel-Off face mask was made using PVA, HPMC, methyl paraben, propylparaben, propylenglycol, extract, ethanol $96 \%$ and aquadest. The rendemen of ethanol $96 \%$ extract was $9,476 \%$, ethyl acetate extract was $0,783 \%$ and $n$-hexane extract was $0,631 \%$. The results of TLC test showed yellow spots on the ethyl acetate and ethanol $96 \%$ extracts which indicated that extract contained flavonoids (anthocyanin). The results of antioxidant activity test showed that IC50 value of ethanol $96 \%$ extract was 189,7422 (AAI=0,2087), ethyl acetate extract was 196,9398 (AAI=0,2011), and n-hexane extract was 385,3664 (AAI=0,1027). The result of the product evaluations showed that all the formulas complied the product requirements such as the organoleptic, homogenity, $\mathrm{pH}$, dispersive power and drying time. Peel-off face mask already meet the product requirements but further research is needed to test the product stability and activity.
\end{abstract}

Keywords: Hylocereuspolyrhizus Haw.; Peel-Off face mask; Anthocyanin; Antioxidant.

\section{Pendahuluan}

Kulit merupakan organ terluar tubuh yang melindungi tubuh dari pengaruh luar dan menutupi seluruh tubuh dari kaki hingga kepala. Kulit khususnya bagian kulit wajah sangat mendukung atau mempengaruhi penampilan seseorang sehingga perlu dijaga, dirawat dan dipelihara kesehatannya. Perawatan kulit sangat perlu dilakukan agar kulit tetap sehat dan terhindar dari kerusakan kulit. Kerusakan kulit biasanya ditandai dengan kulit kusam, keriput, kering, pecah-pecah, bersisik, lebih cepat tua dan muncul flek-flek hitam yang salah satu penyebabnya adalah radikal bebas (Maysuhara, 2009).

Pada zaman sekarang ini radikal bebas terus mengalami peningkatan. Radikal bebas merupakan atom, molekul ataupun senyawa yang dapat berdiri sendiri dan mempunyai elektron tidak berpasangan, bersifat sangat reaktif serta tidak stabil, sehingga sangat mudah bereaksi dengan zat lain seperti protein, lemak maupun DNA dalam tubuh. Faktor yang dapat menyebabkan timbulnya radikal bebas dalam tubuh antara lain sinar UV, asap kendaraan bermotor, bahan kimia dalam makanan, bahan kimia termasuk obat-obatan dan lain sebagainya. Radikal bebas dan reaksi oksidasi yang terjadi ini dapat dihambat oleh suatu senyawa yang disebut antioksidan. Antioksidan adalah suatu senyawa atau komponen kimia yang dalam kadar atau jumlah tertentu mampu menghambat atau memperlambat kerusakan akibat proses oksidasi (Sayuti \& Rina, 2015). Salah satu cara untuk mencegah kerusakan kulit akibat radikal bebas adalah dengan cara mengkonsumsi makanan seperti sayursayuran atau buah-buahan yang banyak mengandung antioksidan (flavonoid, polifenol vitamin $\mathrm{C}$ dan vitamin 
E). Cara lain untuk mencegah kerusakan kulit akibat radikal bebas selain dengan mengkonsumsi makanan yang mengandung antioksidan adalah dengan menggunakan perawatan kulit lain seperti kosmetik yang juga mengandung antioksidan seperti masker wajah. Masker wajah merupakan salah satu sediaan kosmetika yang paling sering digunakan di masyarakat tidak hanya oleh wanita, tetapi juga oleh pria karena cara penggunaan yang mudah dan cepat. Akan tetapi masker wajah yang mengandung antioksidan alami masih sedikit. Oleh karena itu perlu dilakukan pembuatan masker yang mengandung antioksidan dari bahan herbal alami dan memiliki aktivitas antioksidan tinggi.

Salah satu sumber antioksidan adalah pada buah naga termasuk pada kulit buahnya, dimana kulit buah naga memiliki kandungan aktivitas antioksidan jauh lebih besar dibandingkan dengan aktivitas antioksidan pada daging buahnya (Nurliyana et al., 2010). Kulit buah naga mengandung senyawa flavonoid, alkaloid, terpenoid, fenolik, vitamin $\mathrm{C}$, vitamin $\mathrm{E}$ dan vitamin A yang merupakan sumber antioksidan (Jaafar et al., 2009). Masyarakat di NTB khususnya di Kecamatan Jonggat Kabupaten Lombok Tengah, tingkat konsumsi buah naga terutama bauh naga merahnya sangatlah tinggi. Hal ini dikarenakan penanaman buah naga merah dilakukan oleh masyarakat itu sendiri. Akan tetapi pemanfaatan dan penggunaan buah naga hanya terbatas pada konsumsi buahnya saja, sedangkan pemanfaatan dan penggunaan kulit buah naga tidak pernah dilakukan dan hanya dibuang begitu saja. Oleh karena itu peneliti ingin membuat sediaan masker dari ekstrak kulit buah naga merah. Adapun tujuan penelitian ini adalah untuk mengetahui cara mendapatkan ekstrak kulit buah naga merah (Hylocereus polyrhizus Haw.) yang mengandung antosianin tertinggi dengan pelarut berpolaritas berbeda dan mengetahui aktivitas antioksidannya, mengetahui cara pembuatan sediaan masker wajah peel-off ekstrak kulit buah naga merah (Hylocereus polyrhizus Haw.) serta melakukan evaluasi sediaan masker wajah peel-off ekstrak kulit buah naga merah (Hylocereus polyrhizus Haw.).

\section{Bahan dan Metode}

\section{Preparasi Sampel}

Sampel kulit buah naga merah diperoleh dari Desa Bunkate dan Desa Perina Kecamatan Jonggat Kabupaten Lombok Tengah, Nusa Tenggara Barat. Sampel kemudian dideterminasi di Laboratorium Biologi Fakultas Matematika dan Ilmu Pengetahuan Alam (MIPA) Universitas Mataram.

\section{Pembuatan Ekstrak Kulit Buah Naga}

Sampel kulit buah naga merah yang telah diperoleh dicuci dengan air mengalir hingga bersih dan dikupas. Selanjutnya kulit buah naga yang sudah dikupas dipotong dan dikeringanginkan di udara terbuka selama \pm 5 hari. Setelah kering kulit buah naga kemudian diblender hingga diperoleh serbuk simplisia. Simplisia ditimbang sebanyak 200 gram dan dimaserasi dengan etanol 96\%: asam sitrat (4:1) sebanyak 1 L selama 5 hari. Hasil ekstraksi kemudian disaring dengan kertas saring dan dipekatkan dengan rotary vevaporator hingga didapatkan ekstrak kental. Dilakukan hal yang sama dengan menggunakan pelarut etil asetat dan n-heksan (Ingrath et al., 2015).

\section{Identifikasi Antosianin Ekstrak}

Ekstrak etanol, etil asetat dan n-heksan masingmasing dilarutkan dengan sedikit pelarutnya dan ditotolkan pada plat KLT $(4 \times 10 \mathrm{~cm})$ dengan jarak antar spot $1 \mathrm{~cm}$ kemudian dielusi dengan eluen kloroform:etil asetat:n-butanol (5:4:1) dan diamati pada sinar UV 254 $\mathrm{nm}$ dan $366 \mathrm{~nm}$. Selanjutnya plat disemprot dengan aluminium klorida $\left(\mathrm{AlCl}_{3}\right) 10 \%$ dan diamati kembali pada sinar tampak, UV $254 \mathrm{~nm}$ dan $366 \mathrm{~nm}$ (Cahyani et al., 2017).

\section{Uji Antioksidan Ekstrak}

Uji aktivitas antioksidan dilakukan dengan metode DPPH. Sebanyak 50 mg Ekstrak kental kulit buah naga dilarutkan dengan methanol p.a dan dimasukkan ke dalam labu ukur $50 \mathrm{~mL}$. Kemudian ditambahkan methanol p.a hingga tanda batas sehingga didapatkan larutan induk ek strak 1000 ppm. Selanjutnya dari larutan induk dibuat seri konsentrasi 1 ppm, 2 ppm, 3 ppm, 4 ppm dan 5 ppm kemudian diambil masing-masing $2 \mathrm{~mL}$ dan dimasukkan ke dalam tabung reaksi berbeda. Diambil masing-masing $2 \mathrm{~mL}$ dan dimasukkan ke dalam tabung reaksi berbeda kemudian ditambahkan $2 \mathrm{~mL}$ DPPH $0,1 \mathrm{mM}$ dan dihomogenkan dengan vortex. Selanjutnya diinkubasi dalam ruang gelap selama 30 menit dan diukur pada $\lambda$ maks (Molyneux, 2004).

Tabel 1. Formulasi Sediaan Masker Wajah Peel-off

\begin{tabular}{lcccc}
\hline \multirow{2}{*}{ Bahan } & \multicolumn{4}{c}{ Konsentrasi (\%) } \\
\cline { 2 - 5 } & F1 & F2 & F3 & F4 \\
\hline Ekstrak & 0 & 0,25 & 0,5 & 0,75 \\
PVA & 10 & 10 & 10 & 10 \\
HPMC & 1 & 1 & 1 & 1 \\
Propilenglikol & 15 & 15 & 15 & 15 \\
Metil paraben & 0.2 & 0.2 & 0.2 & 0.2 \\
Propil paraben & 0.1 & 0.1 & 0.1 & 0.1 \\
Etanol 96\% & 15 & 15 & 15 & 15 \\
Aquadest & ad 100 & ad 100 & ad 100 & ad 100 \\
\hline
\end{tabular}

\section{Pembuatan Sediaan}

PVA dikembangkan dengan aquades hangat $\left(80^{\circ} \mathrm{C}\right.$ ) (wadah A). HPMC dikembangkan dalam aquades dingin sambil diaduk (wadah B). Metil paraben dan propil paraben dilarutkan dengan propilenglikol (wadah $\mathrm{C}$ ). 
Semua bahan (wadah B dan C) dicampurkan ke dalam wadah A secara berturut-turut dan diaduk hingga homogen. Ekstrak dilarutkan dengan etanol 96\% sedikit demi sedikit dan dicampurkan dengan bahan lainnya sambil diaduk hingga homogen. Selanjutnya ditambahkan aquades hingga 100\% (100 gram) dan diaduk kembali hingga homogeny.

\section{Pengujian Organoleptis}

Sediaan masker yang sudah dibuat diamati bentuk, warna dan baunya. (Septianti \& Mita, 2011).

\section{Pengujian Homogenitas}

Sebanyak 0,1 gram sediaan masker ditimbang kemudian dioleskan pada plat kaca transparan dan dilihat secara visual apakah terdapat bagian yang tidak tercampurkan dengan baik. (Charter, 1997).

\section{Pengujian pH}

Sediaan masker diambil secukupnya dan diiukur pH-nya dengan $\mathrm{pH}$ stick. $\mathrm{pH}$ sediaan masker harus sesuai dengan $\mathrm{pH}$ kulit yaitu 4,5-6,5 (Trenggono \& Latifah, 2007).

\section{Pengujian Daya Sebar}

Sebanyak 0.5 gram sediaan masker diletakkan di atas kaca berukuran $10 \mathrm{~cm}$ dengan kertas berskala di bawahnya. Ditutup dengan kaca lain dan diukur diameter penyebarannya. Selanjutnya di atas kaca ditambahkan beban 10 gram, 30 gram, 50 gram, 70 gram, 90 gram dan 100 gram. Didiamkan selama 1 menit dan diukur diameternya (Naibaho et al., 2013).

\section{Pengujian Waktu Mengering}

Sebanyak 0.3 gram sediaan masker dioleskan pada permukaan kulit dengan ukuran $3 \mathrm{~cm}$ x $3 \mathrm{~cm}$. Didiamkan hingga mengering dan dicatat waktu sediaan mengering. Sediaan dikatakan mengering ketika sediaan dapat dilepas/ditarik dengan mudah.

\section{Analisis Data}

\section{Uji Antioksidan}

Aktivitas antioksidan ditentukan dengan nilai IC50, \%inhibisi dan AAI (Antioxidant Activity Index). Perhitungan IC50 memerlukan data nilai persen inhibisi dari pengujian yang dilakukan, dimana persen inhibisi dapat dihitung dengan menggunakan rumus sebagai berikut: (Ghosal and Mandal, 2012).

$$
\begin{aligned}
& \% \text { inhibisi } \\
& =\frac{\text { absorbansi blanko - absorbansi sampel }}{\text { absorbansi blanko }} \times 100 \%
\end{aligned}
$$

Konsentrasi sampel dan persen inhibisi yang telah diperoleh diplot pada sumbu $\mathrm{x}$ dan $\mathrm{y}$ pada persamaan regresi linear $y=a x+b$. Persamaan tersebut digunakan untuk menentukan nilai IC50 dari masing-masing sampel yang dinyatakan dengan nilai y sebesar 50 dan nilai $\mathrm{x}$ yang akan diperoleh dinyatakan sebagai IC50 (Nurjanah et al., 2011).

Nilai AAI dapat ditentukan dengan cara konsentrasi DPPH yang digunakan dalam uji (ppm) dibagi dengan nilai IC50 yang diperoleh (ppm). Nilai AAI $<0,5$ menandakan aktivitas antioksidan lemah, $0,5 \geq$ AAI $\leq 1$ menandakan aktivitas antioksidan sedang, $1 \geq \mathrm{AAI} \leq 2$ menandakan aktivitas antioksidan kuat, dan AAI >2 menandakan aktivitas antioksidan sangat kuat (Faustino et al., 2010).

\section{Uji Evaluasi}

Data hasil uji evaluasi sediaan dianalisis dengan menggunakan SPSS 16.

\section{Hasil dan Pembahasan}

\section{Pembuatan Ekstrak}

Pembuatan ekstrak diawali dengan proses pengeringan sampel. Pengeringan sampel kulit buah naga yang dilakukan dengan cara diangin-anginkan di udara terbuka dari sampel kulit buah naga segar sebanyak 16.300 gram setelah dihaluskan menghasilkan serbuk simplisia sebanyak 1.150 gram. Simplisia kemudian diekstraksi dengan metode maserasi menggunakan 3 pelarut dengan kepolaran yang berbeda-beda yaitu, nheksan, etil asetat dan etanol $96 \%$ berbanding asam sitrat 10\% (4:1) selama 5 hari. Penggunaan pelarut dengan perbandingan 4:1 dan penambahan asam sitrat dikarenakan sifat antosianin yang stabil pada asam dan dengan perbandingan tersebut menghasilkan akstrak yang paling optimal (Ingrath et al., 2015).

Hasil dari proses maserasi tersebut didapatkan ekstrak cair dengan warna yang berbeda yaitu kuning, oranye dan merah. Perbedaan warna tersebut menunjukkan perbedaan senyawa yang terkandung di dalamnya. Pada dasarnya senyawa antosianin memiliki warna merah pada suasana asam, sehingga dapat diasumsikan bahwa ekstrak etanol 96\% yang memiliki warna merah memiliki antosianin paling tinggi, dilanjutkan dengan ekstrak etil asetat yang berwarna orange dan ekstrak n-heksan yang berwarna kuning. Menurut Fennema (1996), antosianin stabil pada pH 3,5 (asam) sehingga pada kondisi asam atau basa akan mempengaruhi hasil ekstraksi.

Ekstrak cair yang didapatkan kemudian dikentalkan untuk mendapatkan ekstrak kental. Ekstrak kental yang dihasilkan dari ketiga pelarut tersebut, yaitu n-heksan, etil asetat dan etanol 96\% masing-masing sebanyak 1,2627 gram, 1,5670 gram dan 18,9519 gram. Ekstrak yang dihasilkan dengan menggunakan ketiga pelarut tersebut semuanya memiliki warna coklat dengan 
tekstur yang lengket seperti pasta. Semakin banyak ekstrak kental yang dihasilkan menandakan bahwa semakin banyak senyawa yang larut dalam pelarut yang digunakan.

Tabel 2. Karakteristik Ekstrak Cair dan Ekstrak Kental Kulit Buah Naga Merah

\begin{tabular}{|c|c|c|c|c|}
\hline \multicolumn{2}{|c|}{ Karakteristik } & \multirow{2}{*}{$\begin{array}{c}\begin{array}{c}\text { Ekstrak } \\
\text { n-heksan }\end{array} \\
\text { Kuning }\end{array}$} & \multirow{2}{*}{$\begin{array}{c}\begin{array}{c}\text { Ekstrak } \\
\text { etil } \\
\text { asetat }\end{array} \\
\text { Oranye }\end{array}$} & \multirow{2}{*}{$\begin{array}{c}\text { Ekstrak } \\
\text { etanol } \\
96 \% \\
\text { Merah }\end{array}$} \\
\hline Ekstrak & Warna & & & \\
\hline & Volume & $650 \mathrm{ml}$ & $600 \mathrm{ml}$ & $720 \mathrm{ml}$ \\
\hline & Aroma & $\begin{array}{l}\text { Khas n- } \\
\text { heksan }\end{array}$ & $\begin{array}{c}\text { Khas etil } \\
\text { asetat }\end{array}$ & $\begin{array}{c}\text { Khas } \\
\text { etanol } \\
96 \%\end{array}$ \\
\hline \multirow{5}{*}{$\begin{array}{c}\text { Ekstrak } \\
\text { kental }\end{array}$} & Warna & Coklat & Coklat & Coklat \\
\hline & Berat & $\begin{array}{c}1,2627 \\
\text { gram }\end{array}$ & $\begin{array}{c}1,5670 \\
\text { gram }\end{array}$ & $\begin{array}{c}18,9519 \\
\text { gram }\end{array}$ \\
\hline & Aroma & $\begin{array}{l}\text { Khas } \\
\text { ekstrak }\end{array}$ & $\begin{array}{l}\text { Khas } \\
\text { ekstrak }\end{array}$ & $\begin{array}{l}\text { Khas } \\
\text { ekstrak }\end{array}$ \\
\hline & Bentuk & $\begin{array}{c}\text { Kental } \\
\text { seperti } \\
\text { pasta }\end{array}$ & $\begin{array}{c}\text { Kental } \\
\text { seperti } \\
\text { pasta }\end{array}$ & $\begin{array}{c}\text { Kental } \\
\text { seperti } \\
\text { pasta }\end{array}$ \\
\hline & Randemen & $0,631 \%$ & $0,783 \%$ & $9,476 \%$ \\
\hline
\end{tabular}

\section{Identifikasi Antosianin}

Identifikasi antosianin dilakukan secara kualitatif dengan metode KLT. Eluen yang digunakan adalah kloroform:etil asetat:butanol (5:4:1) dan disemprot dengan $\mathrm{AlCl}_{3}$. Penambahan butanol dilakukan untuk membuat eluen menjadi lebih polar karena ketika eluennya tidak terlalu polar maka hasil pemisahan senyawa pada semua ekstrak tidak optimal.

Tabel 3. Data Hasil KLT Ekstrak

\begin{tabular}{cccc}
\hline Ekstrak & Jarak spot $(\mathbf{c m})$ & Warna & Rf \\
\hline n-heksan & 2 & Merah & 0,25 \\
& 7,2 & Oranye & 0,9 \\
Etil asetat & 7,5 & Merah & 0,938 \\
& 0,6 & Kuning & 0,075 \\
& 1 & Biru terang & 0,125 \\
& 1,3 & Kuning & 0,163 \\
& 3,8 & Merah & 0,475 \\
& 6 & Kuning & 0,75 \\
Etanol $96 \%$ & 7,6 & Merah & 0,95 \\
& 0,6 & Kuning & 0,075 \\
& 1,3 & Biru terang & 0,163 \\
& 1,8 & Kuning & 0,225 \\
& 6 & Kuning & 0,75 \\
\hline
\end{tabular}

Hasil dari KLT menunjukkan bahwa antosianin tertinggi terdapat pada akstrak etil asetat dilanjutkan dengan etanol $96 \%$ dan n-heksan. Hasil tersebut ditunjukkan dengan adanya spot berwarna kuning terang dibawah sinar tampak dan kuning berpendar pada sinar
UV $366 \mathrm{~nm}$ yang lebih besar dibandingkan ekstrak lainnya. Senyawa flavonoid ditandai dengan bercak berwarna kuning setelah disemprotkan $\mathrm{AlCl}_{3}$. Menurut Suhendi (2011) senyawa flavonoid atau antosianin ditandai dengan adanya spot kuning redup yang berfluorosensi kuning lemah dengan nilai Rf 0,75. Spot kuning yang dihasilkan memiliki nilai Rf (Retardiation Factor) berbeda-beda yang menunjukan bahwa senyawa flavonoid yang terkandung berbeda, dimana spot tersebut hanya terdapat pada ekstrak etil asetat dan etanol $96 \%$. Nilai Rf untuk spot berwarna kuning pada ekstrak etil asetat adalah 0,$075 ; 0,163$ dan 0,75 , sedangkan nilai $\mathrm{Rf}$ untuk spot berwarna kuning pada ekstrak etanol $96 \%$ adalah 0,$075 ; 0,225$ dan 0,75 . Spot kuning terbentuk karena adanya reaksi pembentukan kompleks antara $\mathrm{AlCl}_{3}$ dengan gugus hidroksi pada senyawa flavonoid (Markham, 1988). $\mathrm{AlCl}_{3}$ bereaksi dengan senyawa flavonoid membentuk suatu kompleks antara gugus hidroksi dan keton atau gugus hidoksi dengan hidroksi lain yang letaknya bertetangga (Khumaira et al., 2017).

\section{Uji Aktivitas Antioksidan Ekstrak}

Uji aktivitas antioksidan ekstrak dilakukan untuk mengetahui apakah ekstrak yang didapatkan memiliki aktivitas antioksidan atau tidak dan ekstrak dengan pelarut manakah yang memiliki aktivitas antioksidan paling tinggi. Metode yang digunakan dalam uji aktivitas antioksidan adalah metode DPPH. Metode DPPH dapat memberikan informasi tentang reaktivitas senyawa yang akan diuji dengan suatu radikal yang stabil. Uji aktivitas antioksidan dengan menggunakan metode DPPH memiliki keuntungan yaitu sederhana, cepat, mudah, peka dan hanya memerlukan sedikit sampel (Hanani et al., 2005).

Tabel 4. Data Hasil Uji Aktivitas Antioksidan Vitamin C

\begin{tabular}{ccccc}
\hline $\begin{array}{c}\text { Konsentrasi } \\
(\mathrm{ppm})\end{array}$ & absorbansi & $\begin{array}{c}\% \\
\text { inhibisi }\end{array}$ & $\begin{array}{c}\text { IC50 } \\
(\mathrm{ppm})\end{array}$ & AAI \\
\hline 5 & 0.0811 & 82.7557 & & \\
4 & 0.1419 & 69.8278 & & \\
3 & 0.1725 & 63.3213 & 2.5252 & 15.6819 \\
2 & 0.2941 & 37.4654 & & \\
1 & 0.3310 & 29.6194 & & \\
Blanko & 0.4703 & 0 & & \\
\hline
\end{tabular}

Tabel 4 menunjukkan nilai absorbansi vitamin $\mathrm{C}$ pada konsentrasi 1-5 ppm mengalami penurunan, sedangkan $\%$ inhibisinya mengalami peningkatan. Nilai IC50 yang menunjukkan bahwa pada konsentrasi 2,5252 ppm vitamin $\mathrm{C}$ dapat menyebabkan hilangnya aktivitas DPPH sebesar 50\%. Nilai IC50 yang kecil menunjukaan bahwa vitamin $\mathrm{C}$ memiliki aktivitas antioksidan yang 
Jani, TA et al. (2020). Jurnal Biologi Tropis, 20 (3): 438 - 445

DOI: http://dx.doi.org/10.29303/jbt.v20i3.2157

tinggi. Hal tersebut juga didukung dengan data AAI >2 yang menandakan aktivitas antioksidan sangat kuat.

Tabel 5. Data Hasil Uji Aktivitas Antioksidan Ekstrak N-Heksan

\begin{tabular}{ccccc}
\hline $\begin{array}{c}\text { Konsentrasi } \\
(\mathrm{ppm})\end{array}$ & absorbansi & $\begin{array}{c}\% \\
\text { inhibisi }\end{array}$ & $\begin{array}{c}\text { IC50 } \\
(\mathrm{ppm})\end{array}$ & AAI \\
\hline 50 & 0,4809 & 5,5577 & & \\
40 & 0,4854 & 4,6740 & & \\
30 & 0,4856 & 4,6347 & 385,3664 & 0,1027 \\
20 & 0,4976 & 2,2781 & & \\
10 & 0,5083 & 0,1767 & & \\
Blanko & 0,5092 & 0 & & \\
\hline
\end{tabular}

Tabel 6. Data Hasil Uji Aktivitas Antioksidan Ekstrak Etil Asetat

\begin{tabular}{ccccc}
\hline $\begin{array}{c}\text { Konsentrasi } \\
(\mathrm{ppm})\end{array}$ & absorbansi & $\begin{array}{c}\% \\
\text { inhibisi }\end{array}$ & $\begin{array}{c}\text { IC50 } \\
(\mathrm{ppm})\end{array}$ & AAI \\
\hline 50 & 0,4577 & 10,1139 & & \\
40 & 0,4604 & 9,5837 & & \\
30 & 0,4783 & 6,0683 & 196,9398 & 0,2011 \\
20 & 0,5021 & 1,3943 & & \\
10 & 0,5047 & 0,8837 & & \\
Blanko & 0,5092 & 0 & & \\
\hline
\end{tabular}

Tabel 7. Data Hasil Uji Aktivitas Antioksidan Ekstrak Etanol 96\%

\begin{tabular}{ccccc}
\hline $\begin{array}{c}\text { Konsentrasi } \\
(\mathrm{ppm})\end{array}$ & absorbansi & $\begin{array}{c}\% \\
\text { inhibisi }\end{array}$ & $\begin{array}{c}\text { IC50 } \\
(\mathrm{ppm})\end{array}$ & AAI \\
\hline 50 & 0,3174 & 14,2626 & & \\
40 & 0,3267 & 11,7504 & & \\
30 & 0,3361 & 9,2112 & 189,7422 & 0,2087 \\
20 & 0,3481 & 5,9697 & & \\
10 & 0,3541 & 4,3490 & & \\
Blanko & 0,3702 & 0 & & \\
\hline
\end{tabular}

Tabel 5, 6 dan 7 menunjukkan nilai absorbansi ekstrak n-heksan pada konsentrasi 10-50 ppm mengalami penurunan, sedangkan \% inhibisinya mengalami peningkatan. Nilai IC50 yang menunjukkan bahwa pada konsentrasi 385,3664 ppm ekstrak n-heksan, 196,9398 ppm ekstrak etil asetat dan 189,7422 ppm ekstrak etanol 96\% dapat menyebabkan hilangnya aktivitas DPPH sebesar 50\%. Nilai IC50 yang kecil menunjukaan bahwa ekstrak n-heksan, etil asetat dan etanol 96\% memiliki aktivitas antioksidan yang rendah. Hal tersebut juga didukung dengan data AAI $<0,5$ menandakan aktivitas antioksidan lemah.

Berdasarkan hasil tersebut di atas, menunjukan bahwa vitamin $\mathrm{C}$ memiliki aktivitas antioksidan atau AAI
(Antioxidant Activity Index) paling tinggi dilanjutkan ekstrak etanol $96 \%$, ekstrak etil asetat dan ekstrak nheksan, dimana aktivitas antioksidan pada ekstrak etanol $96 \%$ dan etil asetat tidak berbeda signifikan $(<0.05)$. Nilai AAI $<0,5$ menandakan aktivitas antioksidan lemah, $0,5 \geq$ AAI $\leq 1$ menandakan aktivitas antioksidan sedang, $1 \geq$ AAI $\leq 2$ menandakan aktivitas antioksidan kuat, dan AAI $>2$ menandakan aktivitas antioksidan sangat kuat (Faustino et al., 2010). Vitamin C sebagai senyawa pembanding memiliki aktivitas antioksidan paling tinggi dikarenakan merupakan senyawa yang pada dasarnya memiliki aktivitas antioksidan yang tinggi pula. Vitamin $\mathrm{C}$ memilki aktivitas antioksidan sangat kuat dengan nilai AAI >2. Ekstrak etanol $96 \%$ memiliki aktivitas antioksidan yang lebih tinggi dibandingkan dengan ekstrak lainnya yang menunjukkan bahwa pada ekstrak tersebut memiliki kandungan senyawa flavonoid atau antosianin tertinggi. Senyawa antosianin termasuk golongan flavonoid yang bersifat polar sehingga dapat diekstraksi dengan menggunakan pelarut yang bersifat polar pula (Fennema, 1996). Senyawa flavonoid yang terdapat pada ekstrak etanol $96 \%$ dan etil asetat diduga merupakan flavonoid yang berikatan dengan gugus gula membentuk dan glikosida sehingga menyebabkan senyawa ini lebih mudah larut dalam pelarut polar seperti etanol, metanol, butanol dan etil asetat (Endang \& Hanani, 2015). Menurut Pratiwi (2016), aktivitas antioksidan senyawa antosianin pada ekstrak etanol lebih tinggi dibandingkan etil asetat maupun n-heksan.

\section{Pembuatan sediaan}

Pembuatan sediaan dilakukan sesuai formula yang ada dengan perbedaan konsentrasi ekstrak yang digunakan pada masing-masing formula. Pembuatan sediaan diawali dengan pengembangan PVA menggunakan aquades hangat $\left(80^{\circ} \mathrm{C}\right)$, dimana Polivinil alkohol merupakan polimer sintetis yang bersifat larut dalam air (Rowe et al., 2009). PVA memiliki sifat yang sangat sulit homogen berupa butiran-butiran kasar dan lengket, sehingga pengembangannya memerlukan perlakuan khusus. Pengembangan PVA dilakukan dengan cara pemanasan di atas holplate dan pengadukan yang sering dan cepat. Pemanasan dan pengadukan cepat akan menyebabkan PVA akan cepat meleleh dan mempercepat pengecilan ukuran partikel PVA sehingga lebih cepat homogen. Hasil dari proses tersebut berupa basis sediaan yang kental, lengket, berwarna putih dan berbusa. Basis sediaan akan menjadi lebih cair dan berwarna setelah ditambahkan bahan lain dan ekstrak serta penyimpanan selama 24 jam untuk menghilangkan busa/gelembung udara yang terbentuk.

Basis sediaan yang telah dibuat kemudian dicampurkan dengan bahan lain seperti HPMC yang sudah dikembangkan. HPMC bersifat larut dalam air dingin, praktis tidak larut dalam air panas (Rowe et al., 2009), sehingga pengembangannya dilakukan dengan 
aquades dingin. Bahan lain yang digunakan adalah metil paraben dan propil paraben yang dilarutkan dalam propilenglikol. Penggunaan kombinasi metil paraben dan propil paraben serta pelarutan dengan propilenglikol dikarenakan aktivitas metil paraben sebagai pengawet dapat ditingkatkan dengan menggunakan kombinasi paraben dengan propil paraben dan penambahan eksipien lain seperti propilenglikol (Rowe et al., 2009). Basis sediaan yang telah dibuat ditambahkan ekstrak yang telah dilarutkan dengan etanol 96\%, dimana etanol berfungsi sebagai pelarut yang memiliki sifat mudah menguap sehingga ketika sediaan diaplikasikan dapat mengering dan membentuk lapisan film (peel-off).

\section{Evaluasi Sediaan}

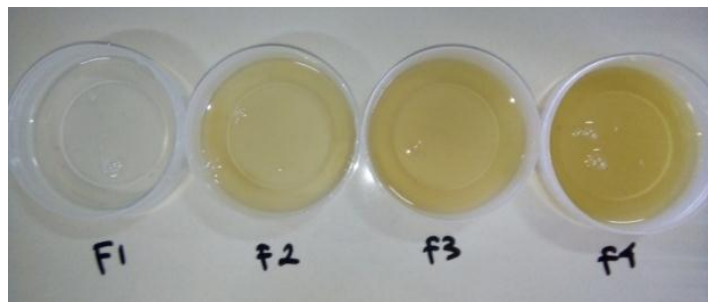

Gambar 1. Sediaan Masker Peel-Off Ekstrak Etanol 96\% Kulit Buah Naga Merah

Uji organoleptis dilakukan untuk mengetahui karakteristik sediaan yang meliputi warna, bau/aroma dan bentuknya. Sediaan yang dihasilkan memiliki karakteristik yang berbeda. Warna sediaan pada formula 1 memiliki warna bening, formula 2 memiliki warna krem pucat, formula 3 memiliki warna krem dan formula 4 memiliki warna coklat muda atau dengan kata lain semakin banyak konsentrasi ekstrak yang digunakan maka warna sediaan yang dihasilkan semakin pekat. Sediaan yang dihasilkan semuanya memiliki aroma khas ekstrak dengan dominasi aroma etanol 96\%. Hal tersebut dikarenakan kandungan etanol di dalam formula yang dibuat mencapai $15 \%$. Konsistensi bentuk sediaan yang dihasilkan memiliki bentuk kental seperti gel dan lengket. Sediaan yang lengket disebabkan karena adanya kandungan polivinil alkohol yang memiliki sifat lengket seperti lem sebanyak $10 \%$ dalam formula.

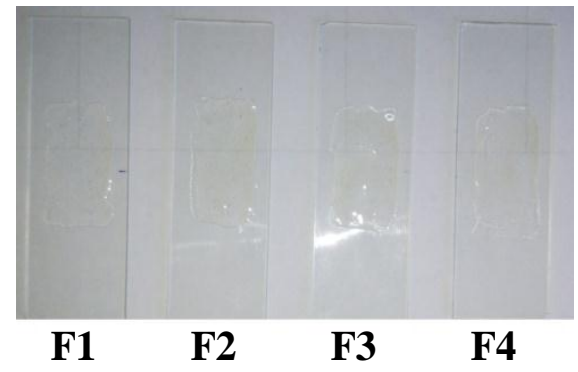

Gambar 2. Hasil uji homogenitas sediaan
Uji homogenitas dilakukan untuk mengetahui apakah sediaan yang dibuat semua bahannya sudah tercampur merata (homogen) atau tidak. Hasil pengujian homogenitas sediaan yang dilakukan dengan cara meletakkan sejumlah sampel pada plat kaca menunjukkan bahwa semua formula homogen. Homogenitas tersebut ditandai dengan tidak adanya partikel-partikel yang tidak tercampur dan tidak adanya partikel-partikel kasar yang terasa ketika dioles dengan jari.

Uji $\mathrm{pH}$ bertujuan untuk mengetahui berapa $\mathrm{pH}$ dari sediaan yang dibuat. Hasil uji $\mathrm{pH}$ sediaan etanol $96 \%$ menunjukkan bahwa nilai $\mathrm{pH}$ 5-6, dimana formula 1 memiliki nilai $\mathrm{pH}$ paling tinggi yaitu 6 dan formula 2, 3 dan 4 memiliki nilai $\mathrm{pH}$ 5. Hal ini menunjukkan bahwa dengan penambahan ekstrak maka $\mathrm{pH}$ sediaan akan semakin rendah sehingga sediaan akan semakin asam. Penurunan $\mathrm{pH}$ sediaan dapat disebabkan karena $\mathrm{pH}$ ekstrak yang bersifat asam, sehingga seharusnya semakin tinggi konsentrasi ekstrak maka pH sediaan akan semakin rendah. Data yang dihasilkan menunjukkan bahwa $\mathrm{pH}$ sediaan dapat dikatakan memenuhi persyaratan sediaan, dimana $\mathrm{pH}$ sediaan masker harus sesuai dengan $\mathrm{pH}$ kulit yaitu 4,5-6,5 (Trenggono \& Latifah, 2007). pH sediaan yang terlalu basa dapat menyebabkan kulit menjadi kering, sedangkan $\mathrm{pH}$ yang terlalu asam dapat menyebabkan iritasi pada kulit.

Tabel 8. Luas Daya Sebar Sediaan

\begin{tabular}{ccccc}
\hline Beban $($ gr) & \multicolumn{4}{c}{ Luas Daya Sebar $\left(\mathbf{c m}^{2}\right)$} \\
\cline { 2 - 5 } & F I & F II & F III & F IV \\
\hline 0 & 13.317 & 13.806 & 13.930 & 14.727 \\
10 & 17.111 & 17.389 & 17.666 & 18.323 \\
30 & 19.528 & 19.822 & 19.823 & 20.871 \\
50 & 21.483 & 21.534 & 21.792 & 23.210 \\
70 & 23.693 & 23.585 & 23.802 & 25.449 \\
90 & 25.337 & 25.393 & 25.674 & 27.037 \\
100 & 26.866 & 26.923 & 27.271 & 29.091 \\
\hline
\end{tabular}

Uji daya sebar dilakukan untuk mengetahui seberapa luas sediaan dapat menyebar ketika diaplikasikan khususnya pada kulit. Hasil uji daya sebar menunjukkan formula F1 memiliki luas daya sebar paling rendah dilanjutkan dengan F2, F3 serta F4 yang memiliki luas daya sebar paling besar. Luas daya sebar sediaan pada beban maksimal (100 gram) F1,F2, F3 dan F4 secara berturut-turut sebesar 26.866, 26.923, 27.271 dan 29.091. Semakin besar beban yang ditambahkan maka semakin besar pula luas daya sebar sediaan karena tekanan yang diberikan akan semakin meningkat pula. Penurunan daya sebar sediaan pada umumnya terjadi karena adanya peningkatan ukuran unit molekul karena telah mengabsorbsi pelarut yang menyebabkan cairan tertahan sehingga meningkatkan ketahanan untuk mengalir dan menyebar (Martin et al, 1993). Menurut Garg et al (2002), syarat daya sebar yang baik untuk sediaan topical adalah memiliki diameter berkisar antara 5-7 $\mathrm{cm}$ atau luas daya 
sebar sekitar 19,625 - 38,465 $\mathrm{cm}^{2}$, sehingga dapat dikatakan bahwa semua formula yang dibuat telah memenuhi persyaratan dan formula yang paling baik adalah F4 karena memiliki daya sebar paling luas.

Uji waktu mengering bertujuan untuk mengetahui berapa lama sedian masker pell-off yang dibuat dapat mengering setelah diaplikasikan khususnya pada kulit. Hasil uji waktu mengering menunjukkan bahwa F1 memiliki waktu mengering paling cepat yaitu 27,31 menit dilanjutkan dengan F2 (28,11 menit), F3 (28,45 menit) serta F4 (28,58 menit) yang memiliki waktu mengering paling lama. Hal yang dapat mempengaruhi waktu mengering sediaan adalah kadar etanol, dimana etanol berfungsi mempercepat waktu mengering sediaan. Ketika etanol menguap, maka kandungan cairan di dalam sediaan akan berkurang sehingga dapat mempercepat waktu mengering. Akan tetapi apabila hal tersebut terjadi pada saat penyimpanan maka sediaan justru akan lebih sulit mengering ketika diaplikasikan (Beringhs et al., 2013). Adapun persyaratan sediaan masker pell-off yang baik apabila memiliki waktu mengering antara 15-30 menit (Vieira, 2009), sehingga dapat dikatakan semua sediaan telah memenuhi persyaratan waktu mengering dengan formula F1 yang memiliki waktu mengering paling baik.

Cara untuk mendapatkan ekstrak kulit buah naga merah yang mengandung senyawa antosianin tertinggi dapat menggunakan metode maserasi dengan pelarut etanol 96\%:asam sitrat (4:1), dimana ekstrak etanol 96\% memiliki aktivitas antioksidan paling tinggi dengan nilai IC50 sebesar 189,7422 (AAI = 0,2087), dilanjutkan dengan ekstrak etil asetat dengan nilai IC50 sebesar 196,9398 (AAI = 0,2011), serta ekstrak n-heksan dengan nilai IC50 sebesar 385,3664 (AAI $=0,1027)$, sehingga aktivitas antioksidan semua ekstrak dikatakan lemah. Pembuatan masker wajah peel-off dilakukan dengan cara mengembangkan PVA dengan aquades hangat sambil dipanaskan dan dicampurkan dengan HPMC yang sudah dikembangkan, metil paraben dan propil paraben yang dilarutkan dalam propilenglikol, serta ekstrak yang dilarutkan dalam etanol $96 \%$ dan diaduk hingga homogen. Semua sediaan telah memenuhi persyaratan uji evaluasi sediaan yang meliputi uji organoleptis, homogenitas, $\mathrm{pH}$, daya sebar dan waktu mengering.

\section{Kesimpulan}

Aktivitas antioksidan tertinggi didapat dari ekstrak etanol 96\% dengan nilai IC50 sebesar 189,7422 ppm $(\mathrm{AAI}=0,2087)$. Empat formula sediaan masker wajah peel-off telah memenuhi syarat sediaan dilihat dari parameter homogenitas, $\mathrm{pH}$, daya sebar, dan waktu mongering.

\section{Ucapan Terima kasih}

Penulis mengucapkan terima kasih kepada Universitas Mataram terutama program studi farmasi, laboratorium farmasetika, dan teman-teman yang telah memberikan dukungan dalam pelaksanaan penelitian ini.

\section{Referensi}

Beringhs, O’Reilly, A., Rosa, J.M. \& Stulzer, H.K. (2013). Green clay and aloe vera peel-off facial masks: response surface methodology applied to the formulation design. AAPS PharmSciTech, 14(1): 445-455. DOI: 10.1208/s12249-013-9930-8.

Cahyani, Rezki, Susanto, Y. \& Khumaidi, A. (2017). Aktivitas Antioksidan dan Sitotoksik Ekstrak Etanol Daun Hantap (Sterculia coccinae Jack.). Journal of Natural Science, 6(1): 11-21. http://jurnal.untad.ac.id/jurnal/index.php/ejurnalfmi pa/article/view/8075 (Accessed on March 9, 2020).

Charter, J.S., (1997). Dispensing for Pharmaceutical Student. $12^{\text {th }}$ Ed. Pitman Medical, London.

Endang, \& Hanani. (2015). Analisis Fitokimia. EGC, Jakarta, pp: 65-104.

Faustino, Helio, Duarte, A.P. \& Cecilia, B. (2010). Antioxidant Activity of Lignin Phenolic Compounds Extracted From Kraft and Sulphite Black Liquors. Molecules, 1(15): 9308-9322. DOI: $10.3390 /$ molecules 15129308 .

Fennema, Owen, R. (1996). Food Chemistry. New York: Marcell Dekker Inc, New York. Pp: 684-686.

Garg, A., Aggarwal, D., Garg, S., Sigla, A.K. (2002). Spreading of Semisolid Formulation: An Update. Pharmaceutical Technology.

Ghosal, M. \& Mandal, P. (2012). Phytochemical Screening and Antioxcidant Activities of Two Selected "Bihi" Fruits Used as Vegetables in Darjeeling Himalaya. International Journal of Pharmacy and Pharmaceutical Science, 4(2):35-46. https://pdfs.semanticscholar.org/a9d7/d699b8580e1 fe654d0de5e671d5e20786a4d.pdf (Accessed on March 9, 2020).

Hanani, E., Mun'im, A. \& Sekarini, R. (2005). Identifikasi Senyawa Antioksidan Dalam Spons calispongia sp Dari Kepulauan Seribu. Majalah Ilmu Kefarmasian, 2(3):127-133. DOI: 10.7454/psr.v2i3.3389.

Ingrath, Windha, Nugroho, W.A. \& Yulianingsi, R. (2015). Ekstraksi Pigmen Antosianin Dari Kulit Buah Naga Merah (Hylocereus Costaricensis) Sebagai Pewarna Alami Makanan Dengan 
Menggunakan Microwave (Kajian Waktu

Pemanasan Dengan Microwave dan Penambahan

Rasio Pelarut Aquades dan Asam Sitrat). Jurnal Bioproses Komoditas Tropis, 3(3): 1-8. https://jbkt.ub.ac.id/index.php/jbkt/article/viewFile/ 182/171 (Accessed on March 10, 2020).

Jaafar, Ali, R., Rahman, A.R.B.A., Mahmod, N.Z.C. \& Vasudevanetl, R. (2009). Proximate Analysis of Dragon Fruit (Hylocereus costaricencis). American Journal of Applied Sciences, 6(7): 106-114. DOI: https://doi.org/10.3844/ajassp.2009.1341.1346.

Khumaira, Sari, A. dan Ayuchecaria, N. (2017). Penetapan Kadar Fenolik Total dan Flavonoid Total Ekstrak Beras Hitam (Oryza Sativa L.) Dari Kalimantan Selatan. Jurnal Ilmiah Ibnu Sina, 2(2): 327-335.

DOI: https://doi.org/10.36387/jiis.v2i2.112.

Markham, K.R. (1988). Cara Mengidentifikasi Flavonoid. Penerjemah Padmawinata, K. ITB, Bandung.

Martin, A., Swarbrick, J. \& Cammarata, A. (1993). Farmasi Fisik: Dasar-dasar Farmasi Fisik dalam Ilmu Farmasetik. Edisi Ketiga. Penerjemah: Yoshita. UI Press, Jakarta.

Maysuhara, S. (2009). Rahasia Cantik, Sehat dan Awet Muda. Edisi I. Pustaka Panasea, Yogyakarta, pp: 4547.

Molyneux, P. (2004). The Use of The Stable Free Radical Diphenylpicrylhydrazyl (DPPH) For Estimating Antioxidant Activity. Journal Science Tachnology, 26(2): 211-219. http://www.thaiscience.info/Journals/Article/SONG /10462423.pdf (Accessed on March 10, 2020).

Naibaho, D.H., Yamkan, V.Y., Weni, Wiyono. (2013). Pengaruh Basis Sediaan Salep Ekstrak Daun Kemangi (Ocinum sanchum L.) Pada Kulit Punggung Kelinci yang Dibuat Infeksi Staphylococcus aureus. Pharmacon, 2(2): 27-33. https://ejournal.unsrat.ac.id/index.php/pharmacon/a rticle/view/1553 (Accessed on June 15, 2020).

Nurjanah, Izzati, L. \& Abdullah, A. (2011). Aktivitas Antioksidan dan Komponen Bioaktif Kerang Pisau
(Solen sp.). Jurnal Ilmu Kelautan, 16(3): 119-124.

DOI: https://doi.org/10.14710/ik.ijms.16.3.119-124.

Nurliyana, R., Zahir, I.S., Suleiman, K.M., Aisyah, M.R. \& Rahim, K.K. (2010). Antioxidant Study of Pulps and Peels of Dragon Fruits: A Comperative Study. International Food Research Journal, 1(17): 367365.

DOI: http://dx.doi.org/10.20473/fmi.v53i4.7152.

Pratiwi, L., Fudholi, A., Martien, R. \& Pramono, S. (2016). Ekstrak Etanol, Ekstrak Etil Asetat, Fraksi Etil Asetat Dan Fraksi N-Heksan Kulit Buah Manggis (Garcinia Mangostiana L.) Sebagai Sumber Zat Bioaktif Penangkal Radikal Bebas. Journal of Pharmaceutical Science and Clinical Research, 1: 71-82. DOI: https://dx.doi.org/10.20961/jpscr.v1i2.1936.

Rowe, Raymond, C., Sheskey, P.J. and Quinn, M.E. (2009). Handbook of Pharmaceutical Excipients. Sixth Edition. Pharmaceutical Press, Chicago London, pp: 17-598.

Sayuti, K. dan Yenrina, R. (2015). Antioksidan Alami dan Sintetik. Andalas University Press, Padang, pp:6-51.

Septianti, S.N. \& Mita, S.R. (2011). Formulasi Sediaan Gel Antioksidan Dari Ekstrak Etanol Biji Melinjo (Gnetum Gnemon Linn.). Jurnal UNPAD., 1(1): 424.http://jurnal.unpad.ac.id/ejournal/article/view/11 75 (Accessed on June 12, 2020).

Suhendi, A., Sjahid, L.R. \& Hanwar, D. (2011). Isolasi dan Identifikasi Flavonoid Dari Daun Dewandaru (Eugenia uniflora L.). Pharmacon, 12(2): 73-81. DOI: https://doi.org/10.23917/pharmacon.v12i2.36.

Tranggono, Iswari, R. \& Latifah, F. (2007). Buku Pegangan Ilmu Pengetahuan Kosmetik. PT. Gramedia Pustaka Utama, Jakarta, pp: 6-7.

Vieira, Rafael, P., Fernandes, A.R., Kaneko, T.M., Consiglieri, V.O., Pinto, C.A.S.D.O., Pereira, C.S.C., Baby, A.R. \& Velasco, M.V.R. (2009). Physical and Physicochemical Stability Evaluation of Cosmetic Formulation Containing Soybean Extract Fermented by Bifidobacterium Animals. Brazilian Journal of Pharmaceutical Sciences, 45(3): 515-525. DOI: 10.1590/S198482502009000300018 . 